\title{
PARTNERSHIP
}

The Canadian Journal of Library and Information Practice and Research

Revue canadienne de la pratique et de la recherche en bibliothéconomie et sciences de linformation

(2021)

Features (editorially reviewed)

DOI: https://doi.org/10.21083/partnership.v16i1.6461

CC BY-NC-ND 4.0

\section{Lists of Opportunities: My Experience as a School Librarian During the COVID-19 Pandemic}

\section{Listes de possibilités : Mon expérience en tant que bibliothécaire scolaire durant la pandémie COVID-19}

Bonnie Morley

School Librarian

Edmonton Public Schools

Bonnie.Morley@epsb.ca

\section{Abstract / Résumé}

In this paper I share my experiences, opinions and perspectives of running a school library during the COVID-19 pandemic. I discuss the difficulties and problems I have encountered, but also the opportunities for creativity that have presented themselves. From experiencing government cutbacks to layoffs and school closures, I discuss my feelings and frustrations about COVID-19 and how it prevented me from doing my job. I demonstrate how the pandemic heightened the feeling of isolation and loneliness in a job that can already make one feel disconnected; I highlight the importance and need for human connection. I also examine the new creative opportunities that working during a pandemic has given me, like asynchronous programming, collection development, professional development and a chance to experiment or renovate. This paper is meant to highlight the importance of school libraries and start a discussion of our role before and after the pandemic. Advocacy helps ensure that school libraries remain open. My goal is to give a glimpse of day-to-day library practice in a school library during the pandemic and share ideas and information with the library and information community. My views and opinions are my own, and the context will be different in every school.

Cet article présente mes expériences, mes opinions et mes points de vue sur la gestion d'une bibliothèque scolaire durant la pandémie de la COVID-19. J'évoque les difficultés et les problèmes que j'ai rencontrés, mais aussi les opportunités de créativité qui se sont présentées. Après avoir subi des compressions gouvernementales, des mises à 
pied et des fermetures d'écoles, je discute de mes sentiments et de mes frustrations à l'égard de la COVID-19 et de la façon dont elle m'a empêchée de faire mon travail. Je démontre comment la pandémie a accentué le sentiment d'isolement et de solitude dans un travail qui peut déjà vous faire sentir déconnecté, tout en soulignant l'importance et le besoin de liens humains. J'examine également les opportunités nouvelles et créatives que le travail pendant une pandémie m'a offertes, comme la programmation asynchrone, le développement de collections, le développement professionnel et la possibilité d'expérimenter ou de rénover. Cet article vise à souligner l'importance des bibliothèques scolaires et à lancer une discussion sur notre rôle avant et après la pandémie. La défense des intérêts joue un rôle pour s'assurer que les bibliothèques scolaires demeurent ouvertes. Mon objectif est de donner un aperçu des pratiques quotidiennes d'une bibliothèque scolaire pendant la pandémie et de partager des idées et des informations au sein de la communauté des bibliothèques. Mes opinions et points de vue sont les miens et le contexte sera différent d'une école à l'autre.

\section{Keywords / Mots-clés}

school libraries, learning commons, COVID-19, pandemic, programming bibliothèques scolaires, carrefour d'apprentissage, COVID-19, pandémie, programmation

\section{Response to COVID-19}

When I talk to people about the COVID-19 pandemic, the conversation inevitably steers toward lists of what we miss. These can include what people miss about going out, what they miss experiencing with family, what they miss about traveling, and so on. Across my school division, libraries are being embraced, repurposed, reconstructed or, in worst cases, abandoned. Given the many factors that shape a school library, such as the community, resources, and finances, library staff must respond to the pandemic in unique ways. This means school librarians constantly have to create and change their lists. Working alone as a school librarian in two junior high school libraries after they closed due to COVID-19 has given me time to create my own "what I miss" list, but it has also given me time and opportunities to try new things.

\section{Changes to State of Mind and Programming}

The first change in my library started with me. Before I could change my programming to reflect "the new normal," I had to change my perception of how my library would be utilized. Typically, most of my job involves interacting with staff and students as well as building connections and relationships. Suddenly, like everyone else, I was instructed to socially distance, essentially making me a customer service representative with no physical customers. I was no longer able to interact face-to-face with people whom I used to see every day. This was probably the hardest experience for me during the whole pandemic; moving from a people-centric job to a more virtual one was very isolating. 
However, once I understood that schools would have a hybrid learning environment with some students online and others bubbled in a classroom, I created a plan for continuing to provide access to library resources and programming. My first hurdle was that students were no longer allowed physically to be in the library space but were still encouraged to read. Thankfully, before COVID-19, I had already subscribed my schools to Overdrive so students could access digital books and audiobooks. During the pandemic, I created videos for online and in-class students, teaching them how to access Overdrive and how to read from home. For students who attended school in person, I created a service called Skip-the-Scan that allowed for online ordering through our online catalogue, Enterprise, with classroom drop-offs. Students could access Enterprise and put school library books on hold, and I would deliver the books to the students' classrooms. This system allowed us to follow social distancing guidelines. The online catalogue had always been available, but I had never encouraged its use, both because students browsed the shelves and borrowed books simultaneously and because I had never taken the time to explore our online catalogue's possibilities. This turned into a great opportunity to explore, play, and learn, resulting in a service I will continue to provide after the pandemic.

The pandemic also made me very aware of options for synchronous and asynchronous interaction and learning. Before COVID-19, my libraries were almost completely built around synchronous interaction, which meant my day started and stopped according to school hours. Students came to see me, or I went to the classroom, and we were restricted to working within the school walls. However, the pandemic has greatly expanded my practices: I can reach staff and students at any time from multiple locations and still allow them to access library programs. To aid in this transition, I have created how-to videos that students can watch independently, designed a website for each library where students can access library news and information, formed an asynchronous book club, and joined classes virtually to teach information literacy lessons. As for my own professional growth, I discovered that access to learning is not limited to my library; in fact, there are many opportunities for me to learn and grow from other organizations hosting relevant conferences and conventions. These opportunities were not often available to me in the past because of budget and travel limitations, but this year many organizations, like the School Library Journal, have made their conferences virtual. As a result, I have been able to attend lectures, panel boards, and author readings, many of which I would not have been able to attend prior to COVID-19.

\section{Cozy with My Collection}

What I lack in face-to-face human companionship, I have more than made up for in stories and books. I might not be able to interact with staff and students in person this year, but I have been able to immerse myself in my collection. Beyond trying to make my library and programs more accessible to staff and students, my main focus this year has been overseeing my books. I have never had so much time to dedicate to updating, learning about, fixing, weeding, reading, cataloguing, and processing my school libraries' collection. My current goal is to at least touch every book on my shelves by the end of the year. This is also a great time to make the catalogue more cohesive and consistent. In the past, I have often discovered an error when I was busy, and I have 
told myself, "One of these days I will go back and fix that." Today is that day. I now have more time to fix those little things on the back burner. In addition, without the heavy foot traffic, I and other school librarians are using this time to reconstruct and restructure our spaces. This is the perfect time to update and rearrange things. I have been experimenting with displays, shelving, decorations, and greenery. I want to change the library's flow and atmosphere for when it opens to the public again.

\section{Budget Cuts and Layoffs}

Of course, this year has had its highs and lows. Some lows were exacerbated by the fact that in March 2020, the United Conservative Party (UCP) education ministry "redirect[ed] \$128 million in funding to the province's COVID-19 response from the school boards" (Omstead, 2020, para. 4). These budgetary changes affected my schools and school board. I and many support staff were laid off as the pandemic began. I believed that the layoffs would be a temporary cost-saving measure until the new school year, when, hopefully, staff and students could return to the classrooms. I am very fortunate to have been rehired as a school librarian, to continue the duties within my job description that utilize my education and training. I do have mixed feelings, however; while I am thankful to continue as a school librarian in these difficult times, many school libraries remain closed and affected colleagues remain laid off or have been reassigned to new positions.

How do we make sure that school libraries open again after the pandemic, supported by library technicians with the skills and training these spaces require to thrive? COVID19 has shown me the vulnerabilities in our school library system. While I understand COVID-19 budgets and priorities are aimed at helping with relief efforts and ensuring the safety of staff and students, I am concerned the diverted funding and staff will have long-lasting consequences for school libraries after the pandemic. Edmonton Public Schools board chair Trisha Estabrooks stated, "We know that to support students in a meaningful way requires more than just teaching staff" (Omstead, 2020, para.10). Without intervention, over time collections become stagnant, borrowing statistics go down, and students have less access and support to literacy tools and resources. My post-COVID-19 wish is that more advocates for school libraries speak up about their importance within the school system so that the necessary funding and qualified staff will be allocated when budget allows.

\section{Reaching Out}

Never has a year highlighted the need for human connection more than this year with COVID-19. The pandemic has prompted school librarians to reach out and communicate with other school librarians. This job tends to make individuals feel like they are alone on an island; they are usually one voice in a school of hundreds. Very few people in my schools understand or share my unique experiences and perceptions. As the only librarian in my schools, I do not often have an opportunity to share ideas, vent frustrations, or collaborate on solutions with other school librarians. This year, however, more school librarians have been pushed to build bridges and reach out to colleagues. Whether for a wellness check or exchange of ideas, school librarians are 
seeing the value of virtually reaching out and building relationships with people who understand our day-to-day struggles and victories.

\section{Conclusion}

The people will always be at the top of my "what I miss" list from the year my school library was closed. I miss the human connection and interaction with staff and students every day. I miss the challenge of trying to get that one reluctant teenager to open a book. I miss the stories. I am very fortunate and thankful for my colleagues and students. They are always supportive when I want to try something new, and they make every effort to connect with me and check on my welfare.

Although I lament my "what I miss" list, working during the pandemic has given me the gift of creativity and time. This is the first year I have had time to examine, evaluate, and change my programming. I have been able to make my library accessible beyond the boundaries of my schools' walls. I am now more familiar with my collection and have combed through its contents. When the library is open to the public, I will be a better school librarian, confident that I know my collection better and that there are more avenues for students to access it. Working in our current atmosphere, I would like to end with one hope: maybe, just maybe, COVID-19 has highlighted how important and integral school libraries are to the education, support, and welfare of our students.

\section{References}

Omstead, J. (2020, March 28). Alberta education cut expected to lay off thousands during pandemic. CBC News. 